\title{
Memórias, subjetivação e educação no tempo presente: como as representações de violência sexual são abordadas nos livros didáticos de História?
}

\begin{abstract}
Resumo
Este artigo tem como tema as representações de violência sexual nas narrativas de 6 coleções de livros didáticos de História, aprovados pelo Programa Nacional do Livro e do Material Didático (PNLD) de 2018, para o Ensino Médio. Trata-se de representações do passado que se apoiam em um conjunto de memórias de violência sexual, especialmente de estupros em cenários de guerra, colonialismo, escravidão e outros conflitos sociais. Com base em estudos feministas interseccionais, busca-se desvelar a historicidade dessas representações, atentando para abordagens, sentidos, discursos e implicações políticopedagógicas nos processos de subjetivação (de gênero/sexualidade) e na educação dos modos de ver, sentir, interpretar e tratar a violência sexual contra mulheres no tempo presente. Com esse intuito, o artigo também apresenta alguns questionamentos e orientações que podem subsidiar os processos de elaboração dos livros didáticos, bem como as formas de abordagem do tema violência sexual no ensino de História.
\end{abstract}

Palavras-chave: Livros Didáticos. Subjetividade. Violência Sexual. História - Estudo e Ensino.

\section{Para citar este artigo:}

OLIVEIRA, Susane Rodrigues. Memórias, subjetivação e educação no tempo presente: como as representações de violência sexual são abordadas nos livros didáticos de História? Tempo e Argumento, Florianópolis, v. 11, n. 28, p. 466 - 502, set./dez. 2019.

DOI: $10.5965 / 2175180311282019466$

http://dx.doi.org/10.5965/2175180311282019466 


\title{
Memories, subjectivation, and education in the present time: how are representations of sexual violence addressed in History textbooks?
}

\begin{abstract}
This article has as its theme the representation of sexual violence in the narratives of 6 History textbook collections, approved by the 2018 National Book and Teaching Material Program (Programa Nacional do Livro e do Material Didático [PNLD]), for High School. These are representations of the past that rely on a set of memories of sexual violence, especially rapes in scenarios of war, colonialism, slavery, and other social conflicts. Based on intersectional feminist studies, we seek to unveil the historicity of these representations, focusing on approaches, meanings, discourses, and political-pedagogical implications in subjectivation processes (gender/sexuality) and in the education related to ways of seeing, feeling, interpreting, and dealing with sexual violence against women in the present time. To this end, the article also brings some questions and guidance that may support the textbook preparation processes, as well as the ways of addressing the theme sexual violence in History teaching.
\end{abstract}

Keywords: Textbooks. Subjectivity. Sexual Violence. History - Study and Teaching.

Ativistas fazem nesta sexta-feira [27/05/2016], no vão do Masp [Museu de Arte de São Paulo Assis Chateaubriand], na Avenida Paulista, em São Paulo, um ato em repúdio ao estupro coletivo a uma jovem de 16 anos, em uma favela do Rio de Janeiro. O caso teve repercussão internacional. A adolescente foi estuprada por 33 homens, e os criminosos postaram as imagens na internet. Os ativistas colaram um cartaz em homenagem à vítima de estupro no Rio e a outras vítimas de violência sexual no mundo inteiro. No cartaz, há a informação de que uma mulher é estuprada no Brasil a cada 11 minutos. Esse dado é do Fórum Brasileiro de Segurança Pública. O número pode ser ainda maior, já que, segundo o Fórum, apenas 30\% dos casos são registrados. Em 2014, mais de 47 mil mulheres foram estupradas no Brasil $(G 1,2016)$. 
Notícias como essa vem ganhando repercussão na mídia brasileira nos últimos anos, graças às intensas mobilizações de movimentos feministas e de mulheres por todo o país. A Marcha das Vadias, o protesto intitulado "Por todas elas", de 2016, e as campanhas veiculadas nas redes sociais com hashtags - "Estupro nunca mais", de 2016, “Estupro não é culpa da vítima”, de 2016, "Eu luto pelo fim da cultura do estupro", de 2016, e "Primeiro assédio", de 2015 (E. S. OLIVEIRA, 2017) - integram uma série de manifestações políticas e culturais nas quais memórias de violência sexual contra mulheres ganham visibilidade e importância, chamando atenção não só para a necessidade de dispositivos jurídicos eficazes de inibição e criminalização da violência sexual, mas, sobretudo, para a necessidade de uma educação para a igualdade de gênero que possibilite a problematização e transformação de histórias, conhecimentos, valores, crenças, imaginários e representações sociais fortemente enraizados em nossa cultura e que ainda sustentam práticas de estupro, assédio sexual, tráfico de mulheres, prostituição forçada, escravidão sexual, dentre outras em contextos de guerra e conflitos sociais.

Como bem observou o historiador Georges Vigarello (1998), a violência sexual nem sempre despertou os mesmos sentimentos, valores e respostas jurídicas. Como outras formas de violência, ela é indissociável do contexto que a produziu, recebendo diferentes sentidos e tratamentos ao longo do tempo e espaço. Inclusive, a vergonha derivada da agressão variou dependendo da identidade da vítima e da imagem que dela se tinha. Tais mudanças em definições, imagens, tratamentos e limites da tolerância da violência sexual denotam, portanto, a historicidade e a força de suas representações na vida social.

As representações se referem ao modo como atribuímos sentidos às coisas:

[...] as palavras que usamos para nos referir a elas, as histórias que narramos a seu respeito, as imagens que delas criamos, as emoções que associamos a elas, as maneiras como as classificamos e conceituamos, enfim, os valores que nelas embutimos (HALL, 2016, p. 21).

Trata-se de elementos constitutivos da linguagem e da comunicação, constantemente elaborados e compartilhados em cada interação social e pessoal (HALL, 2016). Como práticas centrais de produção de valores e significados culturais, são capazes 
de regular e organizar nossos comportamentos, subjetividades e diferenças, auxiliando “no estabelecimentos de normas e convenções segundo as quais a vida em sociedade é ordenada e administrada" (HALL, 2016, p. 22). Ao atuar no nível do corpo, as representações também remetem aos modos de ser engendrados no social, constituindo processos de subjetivação', ou seja, referências com as quais os sujeitos podem se reconhecer e se posicionar na vida social. Assim, partimos do pressuposto de que as representações de violência sexual - difusas nos livros didáticos, nas práticas de ensino, nos sistemas jurídicos, na mídia televisiva, na historiografia, na ciência, no cinema, na música e em outros artefatos culturais da contemporaneidade - têm o poder de orientar práticas sociais, condutas e processos de subjetivação de sexo-gênero, incidindo nas formas de ver, imaginar, interpretar, sentir e tratar essa violência no tempo presente.

Os livros didáticos escolares representam as expectativas e os imaginários coletivos de sociedades escolarizadas, como parte integrante do patrimônio históricoeducativo, constituem fontes imprescindíveis para o estudo da cultura escolar, pois permitem a compreensão do passado formativo comum de diversas gerações e dos padrões que determinam modos coletivos de comunicação e de relação com o mundo (OSSENBACH, 2010, p. 117). Como instrumentos privilegiados de construção das identidades ${ }^{2}$, também funcionam como dispositivos de subjetivação, na medida em que veiculam uma série de representações que nomeiam, descrevem e atribuem valor, significado, identidade, classificação e importância aos sujeitos e suas ações na vida social. Tais representações podem servir de guias, referencias ou modelos para legitimar

\footnotetext{
1 Segundo Foucault (1984, p. 137), a subjetivação é "o processo pelo qual se obtém a constituição de um sujeito, mais exatamente de uma subjetividade, que evidentemente é uma das possibilidades dadas de organização de uma consciência de si". A subjetividade resulta, portanto, de um processo de subjetivação, já que toda experiência que concretiza uma subjetividade envolve modos historicamente peculiares de fazer a "experiência do si". Nessa perspectiva, a subjetividade é "o modo no qual o sujeito faz a experiência de si mesmo num jogo de verdade em que ele está em relação consigo mesmo. Isso remete aos modos de ser engendrados no social, na cultura. Assim, trata-se de uma consciência de si permanentemente em produção, uma formação existencial constituída em um determinado tempoespaço" (HENNIGEN; GUARESCHI, 2006, p. 69).

2 "A partir do século XIX, com a constituição dos estados nacionais e com o desenvolvimento, nesse contexto, dos principais sistemas educativos, o livro didático se afirmou como um dos vetores essenciais da língua, da cultura e dos valores das classes dirigentes. Instrumento privilegiado de construção de identidade, geralmente ele é reconhecido, assim como a moeda e a bandeira, como um símbolo da soberania nacional e, nesse sentido, assume um importante papel político" (CHOPPIN, 2004, p. 553).
} 
ou justificar nossos projetos, bem como escolhas, condutas, relações sociais e modos de ser.

É nesse sentido que elegemos, aqui, os livros didáticos de História como fontes de pesquisa para uma análise histórica das representações de violência sexual que circulam na cultura escolar, especialmente no ensino de História. Trata-se de representações do passado que se apoiam em um conjunto de memórias de violência sexual, sobretudo de estupros em cenários de guerra, colonialismo, escravidão e outros conflitos sociais. Afinal, o que quer dizer essa lembrança evocada nas narrativas didáticas? Como as representações de estupros funcionam no interior dos enredos narrativos? Quem são as vítimas e os perpetradores desses estupros? Como as representações de estupros constroem os sujeitos envolvidos nesses acontecimentos, constituindo processos de subjetivação no ensino de História? Que ordem discursiva e epistêmica abarca essas representações do passado?

Neste artigo, apresentamos uma análise de 6 coleções de livros didáticos de História, aprovados pelo Programa Nacional do Livro e do Material Didático (PNLD) de 2018, para o Ensino Médio. Todas as edições consultadas datam de 2016, já que produzidas em atendimento ao edital publicado em 2015 (PNLD 2018). Na consulta às versões digitais, disponibilizadas temporariamente pelas editoras, em seus respectivos sites, pôde-se detectar enunciados textuais e imagéticos a partir dos seguintes descritores de busca: estupro, estuprada, estuprador, estuprando, estuprar, exploração sexual, violação, violentada, assediada, abusada, prostituir e prostituição.

A partir da constituição de uma amostra significativa de textos, imagens e exercícios, procedemos a uma análise do discurso - atenta às condições de produção, sentidos, significados, regimes de verdade, discursos, valores, crenças, processos de subjetivação de sexo-gênero e modos de funcionamento - das representações de violência sexual nas narrativas didáticas. Trata-se de um tipo de análise do discurso que, em termos foucaultiano, apresenta-se como o estudo de uma prática discursiva ou seja, de um "conjunto de enunciados que formam o substrato inteligível para as ações", capaz de moldar "nossas maneiras de constituir o mundo, de compreendê-lo e de falar sobre eles" (VEIGA-NETO, 2007, p. 93). Como bem explica Hall (2016, p. 27), o principal objetivo 
dessa abordagem consiste em historicizar discursos, representações, conhecimentos e verdades, considerando o modo "como o conhecimento elaborado por determinado discurso se relaciona com o poder, regula condutas, inventa ou constrói identidades e subjetividades", definindo as maneiras como "certos objetos são representados, concebidos, experimentados e analisados”. Com esse intuito, também apresentamos questionamentos e orientações que podem subsidiar os processos de elaboração dos livros didáticos, bem como as formas de abordagem do tema violência sexual no ensino de História.

Os livros didáticos de História, enquanto elementos curriculares de orientação e difusão de saberes históricos a serem escolarizados, produzem e veiculam uma série de representações do passado que educam nossas maneiras de ver, julgar, pensar e posicionar-se perante certos acontecimentos, comportamentos, sujeitos, práticas e relações sociais, tanto do passado como do presente. Por isso, não se trata de narrativas históricas inocentes ou despretenciosas. Como formas de interpretação e produção de sentidos para o passado, tais narrativas são mediadas pela cultura e pelos interesses do presente, sempre marcadas por relações de poder que respondem a leis, padrões e critérios implícitos de controle da educação escolar, sistematizados ao longo da institucionalização dos sistemas públicos de ensino (OSSENBACH, 2010, p. 120).

Entendemos que o conhecimento histórico é construído a partir de memórias sociais. Segundo Gnecco (2000, p. 171, tradução nossa),

[...] a memória social é tudo aquilo que os indivíduos recordam de suas experiências locais, regionais e, em menor grau, extrarregionais. Porém, a significação da memória social é flutuante, quase idiossincrática. Sua precisão semântica - a fixação de seu significado no marco de projetos de construção de sentido - ocorre através da historia, que dessa maneira aparece como sua consequência.

A história funciona como uma tecnologia de domesticação (colonização, estruturação) da memória social. Ainda segundo o autor, "o controle histórico da memória social está profundamente atravessado por relações de poder, pois seu lócus não é o passado mas o presente e o futuro" (GNECCO, 2000, p. 172, tradução nossa). Os livros didáticos de História, assim como a produção historiográfica e outros artefatos culturais que difundem representações do passado, estão entre os diversos agentes 
desse processo, haja vista que um dos elementos determinantes da estruturação e mobilização de coletivos sociais é a história, "entendida como uma prática social que cria referenciais temporais precisos sobre o passado" (GNECCO, 2000, p. 171, tradução nossa). Nesse sentido,

[...] o currículo de história é um produto de escolhas que estabelece um modo de recortar e contar o passado, de criar referências ao presente e estabelecer o que deve se tornar uma memória, compondo, consequentemente, uma base para a identidade de todos os brasileiros (PEREIRA; RODRIGUES, 2018, p. 3).

Portanto, nos livros didáticos de História, as memórias ganham status formativo como recursos pedagógicos de subjetivação e ordenamento/governabilidade das relações sociais. Aqui, não queremos atribuir ao livro didático a total responsabilidade e poderes na formação das subjetividades e relações de poder marcadas pela violência sexual. No entanto, esses livros funcionam como dispositivos pedagógicos e culturais de amplo alcance em nossa sociedade. Por meio do PNLD, o governo brasileiro compra milhares de exemplares e distribui gratuitamente às escolas públicas de todo o país. Apesar de sujeitos a múltiplos usos e apropriações por parte de professores e estudantes na Educação Básica, eles ainda são o principal material de leitura e aprendizado escolar, além de referências curriculares, guias metodológicos de ensino e suportes privilegiados de memórias que colaboram na fixação de determinados sentidos para os acontecimentos passados.

Enquanto "registros de memórias de diferentes temporalidades", os livros didáticos "evidenciam esforços do presente na reelaboração do passado e indicam determinadas formas de interpretar que resistem ao tempo" (BECHLER; SILVA, 2019, p. 1). Ao mesmo tempo que buscam difundir representações oficias ou canônicas da história nacional, a fim de propagar ou fixar uma visão coerente do passado, tais livros se revelam pontos de confluência de uma série de discursos sobre o passado (BECHLER; SILVA, 2019, p. 11). Marcados por discursos hegemônicos, mas também por debates sociais controversos, "refletem de uma ou de outra forma controvérsias sociais sobre temas sensíveis da memória. Não raramente, tudo isso confere às narrativas didáticas tensões e ambivalências" (CHRISTOPHE apud BECHLER; SILVA, 2019, p. 11-12). Assim, os livros 
didáticos carregam as marcas de permanências e mudanças nos sistemas e ideários políticos, bem como nas concepções e discussões produzidas em âmbitos pedagógicos, historiográficos, editorais e sociais (MISTURA; CAIMI, 2015).

Não por acaso, os livros didáticos de História se inscrevem em um ambiente pedagógico específico e regulador (CHOPPIN, 2004, p. 554), onde confluem tradições, memórias, expectativas docentes, políticas curriculares oficiais, tendências historiográficas, interesses editoriais, demandas sociais e discursos que conformam a especificidade dos saberes escolares. Dentre as normas que definem os saberes históricos a serem ensinados, destacam-se as prescrições do PNLD que, desde os anos 1990, vem efetuando reformulações positivas importantes de valorização da formação para a cidadania, para o convívio com a diversidade e a pluralidade social, propondo para isso o tratamento de questões de gênero, relações étnico-raciais, diversidade, homofobia, direitos humanos, discriminação racial e violência nos livros didáticos. Em atendimento às demandas de alguns movimentos sociais (de direitos humanos, mulheres, feministas, negros, indígenas, lésbicas, gays, bissexuais, travestis, transexuais ou transgêneros [LGBTs] e povos do campo) observamos que o edital do PNLD de 2018 para o Ensino Médio estabeleceu, dentre seus princípios, que as coleções submetidas à avaliação deviam:

1.1.2. abordar a temática de gênero, visando à construção de uma sociedade não sexista, justa e igualitária, inclusive no que diz respeito ao combate à homo e transfobia;

1.1.3. proporcionar o debate acerca dos compromissos contemporâneos de superação de toda forma de violência, com especial atenção para o compromisso educacional com a agenda da não violência contra a mulher;

1.1.4. promover a educação e cultura em direitos humanos, afirmando os direitos de crianças e adolescentes, bem como o conhecimento e vivência dos princípios afirmados no Estatuto do Idoso;

1.1.5. incentivar a ação pedagógica voltada para o respeito e valorização da diversidade, aos conceitos de sustentabilidade e da cidadania, apoiando práticas pedagógicas democráticas e o exercício do respeito e da tolerância;

1.1.6. promover positivamente a imagem de afrodescendentes e dos povos do campo, considerando sua participação e protagonismo em diferentes trabalhos, profissões e espaços de poder; 
1.1.7. promover positivamente a cultura e história afro-brasileira e dos povos indígenas brasileiros, dando visibilidade aos seus valores, tradições, organizações, conhecimentos, formas de participação social e saberes sociocientíficos, considerando seus direitos e sua participação em diferentes processos históricos que marcaram a construção do Brasil, valorizando as diferenças culturais em nossa sociedade multicultural; 1.1.8. abordar a temática das relações étnico-raciais, do preconceito, da discriminação racial e da violência correlata, visando à construção de uma sociedade antirracista, solidária, justa e igualitária (BRASIL, 2015, p. 32, grifo do autor).

Além dessas prescrições para os livros didáticos, a Base Nacional Comum Curricular (BNCC) também prescreve a formação de competências e habilidades para o posicionamento crítico e o enfretamento do problema da violência no tempo presente. Dentre as competências específicas das Ciências Humanas e Sociais aplicadas ao Ensino Médio, destaca-se a formação para o reconhecimento e combate às "diversas formas de desigualdade e violência, adotando princípios éticos, democráticos, inclusivos e solidários, e respeitando os Direitos Humanos" (BRASIL, 2017a, p. 564). Para isso, propõe o desenvolvimento da habilidade de "identificar diversas formas de violência (física, simbólica, psicológica etc.), suas causas, significados e usos políticos, sociais e culturais, avaliando e propondo mecanismos para combatê-las, com base em argumentos éticos" (BRASIL, 2017a, p. 564).

Nesse exercício, diz ainda que

[...] é fundamental abordar circunstâncias da vida cotidiana que permitam desnaturalizar condutas, relativizar costumes, perceber a desigualdade e o preconceito presente em atitudes, gestos e silenciamentos, avaliando as ambiguidades e contradições presentes em políticas públicas tanto de âmbito nacional como internacional (BRASIL, 2017a, p. 564).

No entanto, as formas de inclusão das mulheres e de questões ligadas à violência nos livros didáticos dependem não só do modo como tais orientações são interpretadas e ressignificadas por autores e editoras, mas, sobretudo, da ordem discursiva e epistêmica que predomina na cultura escolar. Como bem descreve Dominique Julia (2001, p. 11), a cultura escolar constitui um 
[...] conjunto de normas que definem conhecimentos a ensinar e condutas a inculcar, e um conjunto de práticas que permitem a transmissão desses conhecimentos e a incorporação desses comportamentos; normas e práticas coordenadas a finalidades que podem variar segundo as épocas (finalidades religiosas, sociopolíticas ou simplesmente de socialização).

A violência sexual se situa entre os temas sensíveis e polêmicos que há muito tempo vêm sendo evitados na cultura escolar e no ensino de História. Não por acaso, trata-se de uma modalidade de violência bastante silenciada e pouco denunciada em nossa sociedade, onde ainda é vista e tratada como um tabu relacionado à intimidade, à vida íntima das famílias, à sexualidade, à fantasia, à insanidade, ao erotismo ou às perversões sexuais. No entanto, o contexto atual tem desafiado a escola a se posicionar diante das desigualdades e injustiças sociais vivenciadas pelos próprios estudantes em seu cotidiano, o que também envolve casos de violência sexual. Os professores vêm sendo mobilizados para a prevenção e denúncia de casos de violência sexual sofrida por crianças e adolescentes (VIZA; SARTORI; ZANELLO, 2017). Além de enfrentar os enormes desafios da vigilância e comunicação em casos suspeitos de estupro, assédio ou abuso sexual contra menores, esses professores também sofrem com a falta de materiais didáticos adequados para a abordagem do tema violência sexual em sala de aula, sobretudo em razão de movimentos reacionários e fundamentalistas que, recentemente, vêm tentando impedir a inclusão da temática gênero nos currículos escolares (MISKOLCl, 2018), criminalizando, perseguindo e restringindo a liberdade de expressão dos professores em sala de aula, destruindo, assim, o potencial educacional da escola.

Diante dessa situação, enquanto professores e historiadores, entendemos que é necessário analisar e discutir o modo como a violência sexual vem sendo incorporada, rememorada e ressignificada nos livros didáticos de História. "Para que o ensino de história contribua na igualdade entre os sexos e no fim da violência contra as mulheres, é necessário empreender uma desnaturalização de comportamentos e relações humanas que a história nos mostra como dados e não como construções" (S. R. OLIVEIRA, 2017, p. 223). Nesse sentido, revelar a historicidade dos sentidos constitutivos de narrativas históricas de violência sexual é parte fundamental de nosso compromisso político com a educação para a transformação das formas misóginas, racistas e sexistas de pensar e agir 
que ainda produzem a vitimização, a opressão e o sofrimento das mulheres no tempo presente (S. R. OLIVEIRA, 2014). Para isso, buscamos apoio teórico em estudos feministas interseccionais (pós-estruturalistas, pós-coloniais, decoloniais e negros) ${ }^{3}$, bem como nas noções de representação (HALL, 2016) e subjetivação (FOUCAULT, 1984).

A violência sexual contra as mulheres continua sendo um problema tão sério hoje como foi nos anos 1970 (BERTRAM; CROWLEY, 2012). Por isso, os estudos feministas vêm há muito tempo apontando o caráter patriarcal, racista e sistêmico da violência sexual, colaborando na crítica e historicização de representações e discursos que naturalizam4, sexualizam e erotizam tais atos de opressão e até o assassinato (feminicídio) de mulheres. Com um olhar atento às interseccionalidades do gênero - raça, classe, etnia e outros marcadores sociais - alguns estudos problematizam a violência sexual como "um conjunto complexo de práticas culturais usadas para impor e manter não apenas o sexismo, mas também múltiplas formas de opressão" (BERTRAM; CROWLEY, 2012, p. 63, tradução nossa). A realidade vivida do trauma sexual constitui, assim, uma "representação corporal do poder" (BERTRAM; CROWLEY, 2012, p. 63, tradução nossa) capaz de articular as estruturas sistêmicas de exploração e opressão à experiência da agressão e dominação sexual.

A violência sexual simboliza e expressa uma relação de poder que constrói posições subjetivas para vítimas/femininas e agressores/masculinos. Ao desencadear processos de subjetivação desiguais que engendram e reificam representações de sexogênero5, funciona, ainda, como uma tecnologia de gênero (LAURETIS, 1994). Lauretis

\footnotetext{
${ }^{3} \mathrm{~A}$ análise interseccional do gênero evita incorrer em generalizações que tendem a apagar a diversidade de experiências e de relações de gênero na compreensão histórica da violência sexual contra mulheres. É com esse olhar que buscamos um entendimento mais amplo e dinâmico das representações de violência sexual contra mulheres nas narrativas didáticas, indo mais além da noção de um patriarcado hegemônico/universal, ao permitir desvelar aspectos raciais, étnicos, políticos, econômicos e culturais que se articulam a tais representações.

${ }^{4}$ Alguns estudos no campo da sociobiologia tentam demonstrar que o estupro é um impulso natural, adaptativo e positivo. Suas conclusões derivam de experimentos e observações de várias espécies de animais (cf. THORNHILL; PALMER, 2000). Malcolm Potts e Thomas Hayden (2008) defendem a ideia de que o estupro é algo profundamente incrustado na natureza dos homens e que desde a pré-histórica, quando as guerras começaram, os estupros vêm sendo usados como armas de guerra para humilhar o inimigo e destruir a alma de sua socidade.

5 O sistema de sexo-gênero "é tanto uma construção sociocultural quanto um aparato semiótico, um sistema de representação que atribui significado (identidade, valor, prestígio, posição de parentesco, status dentro da hierarquia social etc.) a indivíduos dentro da sociedade" (LAURETIS, 1994, p. 212).
} 
(1994, p. 208) explica que o gênero, enquanto representação e autorrepresentação, "é produto de diferentes tecnologias sociais, como o cinema, por exemplo, e de discursos, epistemologias e práticas críticas institucionalizadas, bem como das práticas da vida cotidiana”. É nesse sentido que destacamos as práticas de violência sexual, bem como suas memórias e histórias, como tecnologias de gênero, pela capacidade de engendrar processos de subjetivação que também sustentam e mantêm desigualdades estruturais em nossa sociedade.

\section{Estupros coletivos na Idade Média}

Em uma atividade localizada ao final de um capítulo dedicado à cultura, economia e sociedade medieval, no primeiro volume da coleção Olhares da História (B. VICENTINO; C. VICENTINO, 2016), identificamos uma menção aos estupros coletivos em tempos medievais. A atividade, incluída na seção intitulada "Pratique" ${ }^{6}$, é desencadeada pela leitura do seguinte fragmento de texto historiográfico:

11. Em um artigo sobre os jovens na Itália medieval, a historiadora Elisabeth Crouzet-Pavan explica:

Os arquivos criminais atestam numerosas práticas anômicas ou criminosas que congregam os bandos de jovens. E essas práticas, em Veneza, são características das horas noturnas. O estupro coletivo, diferente de muitos estupros diurnos cometidos no espaço da cidade ou da casa, inscreve-se no registro dessas violências perpetradas à noite. Os componentes lúdicos que lhe são inerentes, as injúrias e os golpes que o acompanham, seguem as regras gerais que dramatizam a conduta violenta do grupo. $O$ estupro, como todas as outras formas de agressão noturna, prova, no seio do grupo, uma capacidade social baseada essencialmente em critérios de virilidade. A violência contra as forças policiais vale igualmente como proeza viril. A luta é exigida pelas regras da honra quando, de armas na mão, o grupo recusa-se a deixar-se revistar. Mas, com frequência, a briga é voluntária, provocada por uma troca preliminar de insultos ou uma gritaria geral. Sem outra causa a não ser a escolha precisa desse adversário, observa a sentença, cinco ou seis

\footnotetext{
${ }^{6}$ De acordo com o Manual do Professor, as atividades dessa seção "trabalham habilidades operacionais e interdisciplinaridade. Envolvem leitura, análise, comparação, interpretação de imagem, de textos e documentos diversos, letras de música, poesias, charges, tabelas, mapas etc. Nessas atividades tentamos criar condições para que o aluno perceba: primeiro, que a História ensinada na obra e na escola não é a única fonte de informação que ele tem disponível (realizações práticas e interpretações da História que brotam das famílias, instituições e meios de comunicação também devem ser consideradas); segundo, que a História está em permanente construção" (B. VICENTINO; C. VICENTINO, 2016, p. 292).
} 
delinquentes atacam as forças policiais do Conselho dos Dez. O jogo se prolonga. Quatro jovens, intimados a entregar suas armas, lutam de espada com um guarda, obrigam-no a refugiar-se numa casa, perseguindo-o até afinal feri-lo. [...] Os primeiros textos regulamentares das Comunas, na segunda metade do século XIII e nas primeiras décadas do século seguinte, lançavam as bases de um controle dos comportamentos. Trata-se então de um primeiro dispositivo de conjunto que, destinado a pacificar a cidade, visava [a] certas práticas, protegendo mais particularmente alguns períodos e alguns lugares. [...]

CROUZET-PAVAN, Elisabeth. Uma flor do mal: os jovens na Itália medieval (séculos XIII-XV). In: LEVI, Giovanni; SCHMITT, Jean-Claude. História dos jovens. São Paulo: Companhia das Letras, 1996. v. 1, p. 204-205.

a) O que caracterizava o comportamento dos jovens nas cidades medievais?

b) Como as autoridades lidavam com os bandos jovens que agiam nas cidades?

c) Formem grupos de cinco ou seis pessoas e durante uma semana pesquisem e selecionem notícias que tratam do jovem hoje na cidade. Que imagem a imprensa constrói do jovem?

d) A maneira como as autoridades lidam com o jovem hoje é diferente ou parecida com a forma como lidavam com eles na Idade Média? Explique.

e) Em sua opinião, a imagem construída pela imprensa traduz com fidelidade a juventude de hoje? Justifique (B. VICENTINO; C. VICENTINO, 2016, p. 244, grifo nosso).

As atividades propostas em torno do recorte historiográfico abrem importantes reflexões sobre as experiências de jovens urbanos, a partir das representações produzidas pela imprensa7, mas deixam escapar a problematização de um tema sensível no tempo presente, os estupros coletivos como forma de violência e idealização de masculinidades dominantes. As questões "a" e "b", marcadas pela insígnia dos pronomes interrogativos "o que" e "como", são estritamente descritivas e, desse modo, remetem a uma aprendizagem baseada na memorização, por meio da reprodução literal daquilo que é dito no texto ${ }^{8}$. Trata-se de questões que tendem a fixar os conteúdos ao invés de colocá-los em discussão ou problematização em sala de aula.

7 O Guia Digital do PNLD, em suas análises, destaca que essa obra "problematiza aspectos ligados à construção de estereótipos e de imagens negativas de determinados grupos, de forma a possibilitar o respeito aos princípios éticos e à diferença" (BRASIL, 2017b, p. 32).

${ }^{8}$ O Manual do Professor apresenta as seguintes respostas para essas questões: "a) O comportamento dos jovens nas cidades medievais era violento e insubordinado. Os jovens reuniam-se em bandos e durante a noite cometiam diversos tipos de crime, como estupros coletivos e badernas. Caso a polícia tentasse contê-los, reagiam e não se rendiam à autoridade da Comuna. [...] b) As autoridades buscavam controlar os jovens, primeiro reprimindo suas ações violentas. A partir da segunda metade do século XIII, foram criados os primeiros textos regulamentares das Comunas a fim de controlar os comportamentos dos 
Já as questões "c", "d" e "e", ao direcionar o debate para o tempo presente, apenas ao modo como as autoridade e a imprensa lidam com os jovens urbanos na atualidade, enfatizando as diferenças e as imagens positivas e negativas dos jovens, deixam escapar não só a possibilidade de historicização de imagens que constroem masculinidades agressoras/estupradoras, como também a atualidade deste tema entre a juventude. Não por acaso, o Manual do Professor ${ }^{9}$ orienta uma aprendizagem que aponta a distinção entre "realidade" e "imagem", simplificando o entendimento do mundo social e, assim, ignorando a força das imagens na construção das subjetividades e práticas dos jovens tanto do passado como do presente.

O recorte historiográfico que embasa essas atividades revela que os estupros coletivos nas noites de Veneza eram parte de uma confraria masculina associada à criminalidade, onde a violência sexual contra mulheres e a violência armada contra as forças policiais ganham contornos de jogo e ludicidade na expressão de uma subjetividade viril que serve como prova da capacidade de cumprir as "regras da honra" que fundamentam a identidade do grupo. Ao mesmo tempo que confere visibilidade a

jovens e pacificar as cidades" (B. VICENTINO; C. VICENTINO, 2016, p. 371).

9 De acordo com o Manual do Professor: "c) Resposta pessoal. O objetivo da atividade é propiciar uma reflexão sobre as experiências de jovens urbanos, a partir das representações produzidas pela imprensa. Espera-se que a pesquisa acesse um conjunto variado de artigos e reportagens sobre práticas sociais contemporâneas, como os bailes funk, as diferentes "tribos" urbanas, as ONGs ligadas ao meio ambiente (geralmente, com participação predominante de jovens) e as diversas formas de entretenimento que reúnem os jovens (como casas de show, praças, locais para dançar ou se conhecer). Também devem surgir notícias e reflexões sobre a violência de que são vítimas os jovens das periferias das grandes cidades e sobre a violência praticada por grupos armados (ligados ou não ao tráfico) e grupos de neonazistas. Instrua os alunos para identificarem elementos recorrentes entre as notícias. A seguir, oriente-os a separar as notícias encontradas entre aquelas que traçam um perfil positivo do jovem e aquelas que o representam como ameaça. Algumas perguntas que podem nortear a reflexão e a análise das notícias são: Quando o jovem é mostrado de maneira positiva? Quando a imagem é negativa? Todos os jovens (do sexo masculino ou feminino, ricos ou pobres, brancos ou negros etc.) são tratados da mesma forma ou é feita alguma distinção entre eles? Que adjetivos são empregados para se fazer referência aos jovens? [...] d) Resposta pessoal. Espera-se que os alunos reflitam sobre a diversidade no tratamento oferecido aos jovens no mundo contemporâneo. Em linhas gerais, pode-se apontar que os jovens pobres, moradores das periferias, são atingidos por práticas violentas do Estado, especialmente, por meio da ação da polícia, mas também por terem suas expressões culturais estigmatizadas e excluídas do circuito cultural da cidade. Os jovens de outras classes sociais podem não sofrer essa violência, no entanto também são alvo de mecanismos de controle que procuram conduzi-los a aceitar os valores sociais predominantes, especialmente a ideologia do trabalho, e que tendem a definir e exigir padrões de comportamento e moralidade. [...] e) Resposta pessoal. Espera-se que os alunos reconheçam que a imprensa produz um determinado ponto de vista sobre a juventude e não uma visão objetiva e fiel. Isso pode ser colocado em debate, tendo em vista a própria realidade dos alunos e de sua comunidade. Afinal, raramente os grandes meios de comunicação conseguem apresentar as especificidades locais e tendem a produzir sínteses generalizadoras sobre a juventude" (B. VICENTINO; C. VICENTINO, 2016, p. 371). 
um modelo agressivo de masculinidade, destaca a importante presença de dispositivos normativos de pacificação e controle dos comportamentos naquele contexto. Entretanto, o recorte demonstra que os estupros coletivos, seguidos de golpes e insultos, bem como as brigas e a luta armada nos espaços públicos, como representações de poder viril, fundamentavam o comportamento dos homens em grupo, especialmente as formas de atuação que exigiam demonstração de coragem, força e honra na capacidade de burlar as normas sociais. Essa representação de virilidade, suscitada pelo campo da representação do estupro, conduz a um imaginário da sexualidade que distingue radicalmente os lugares do masculino e do feminino na história, já que se passa sem qualquer problematização. Como bem afirma Lia Machado (1998, p. 251):

O estupro é muito mais o lugar do exercício da afirmação da identidade masculina especular, em que a subjugação do corpo da mulher reassegura sua identidade masculina e reafirma o caráter sacrificial dos corpos das mulheres. Do estupro realizado tipicamente nas ruas, onde não importa quem é a mulher, mas apenas se busca a disponibilidade do corpo, ao estupro que nomeia como objeto uma mulher específica, a virilidade oscila entre a reafirmação por excesso da concepção da sexualidade masculina como único lugar de iniciativa e do apoderamento sexual do corpo do outro e o uso da concepção da sexualidade masculina como instrumento de reafirmar o poder social sobre o gênero feminino. A metáfora sexual serve à metáfora social na reafirmação do englobamento hierárquico do lugar simbólico do feminino em relação ao lugar simbólico do masculino.

Os estupros coletivos como dispositivos de construção/reafirmação de masculinidades estão intimamente associados "à exibição performativa de força de um determinado grupo para si (direcionado aos próprios homens como prova de masculinidade) e para o outro (a vítima, que é subjugada)" (NUPEGRE, 2018, p. 28). Desse modo, como explica Kimmel (1998, p. 105), as masculinidades são construídas “simultaneamente em dois campos inter-relacionados de relações de poder - nas relações de homens com mulheres (desigualdade de gênero) e nas relações dos homens com outros homens (desigualdades baseadas em raça, etnicidade, sexualidade, idade etc.)".

O recorte historiográfico não problematiza a normalidade dos estupros coletivos nem a construção de masculinidades de homens que precisavam demonstrar virilidade e 
dominação de corpos femininos, embora forneça possibilidades para isso ${ }^{10}$. Porém, os autores do livro didático privilegiam questões que não atingem os significados e usos políticos da violência sexual perpetrada contra as mulheres naquele contexto. Questionase a imagem dos jovens na imprensa, mas nada a respeito daquele modelo de masculinidade agressora que emerge nas cidades medievais. Como bem disse Kimmel (1998, p. 105), a “masculinidade como uma construção imersa em relações de poder é frequentemente algo invisível aos homens cuja ordem de gênero é mais privilegiada com relação àqueles que são menos privilegiados por ela e aos quais isto é mais visível”. Não por acaso, a violência sexual emerge no livro didático sem qualquer problematização que possibilite seu enfrentamento no tempo presente, correndo o risco de reforçar um suposto vínculo natural entre masculinidade e agressão sexual às mulheres na história.

A educação para o combate à violência sexual no tempo presente também exige um reconhecimento da historicidade das masculinidades, ou seja, do modo como elas são construídas socialmente, pois não se trata de "uma propriedade de algum tipo de essência eterna, nem mítica, tampouco biológica” (KIMMEL, 1998, p. 105).

Ainda segundo Kimmel (1998, p. 106),

[...] os significados de masculinidade variam de cultura a cultura, variam em diferentes períodos históricos, variam entre homens em meio a uma só cultura e variam no curso de uma vida. Isto significa que não podemos falar de masculinidade como se fosse uma essência constante e universal, mas sim como um conjunto de significados e comportamentos fluidos e em constante mudança. Neste sentido, devemos falar de masculinidades, reconhecendo as diferentes definições de hombridade que construímos. Ao usar o termo no plural, nós reconhecemos que masculinidade significa diferentes coisas para diferentes grupos de homens em diferentes momentos.

O tratamento da violência sexual como parte onipresente da história dificulta a capacidade de nossos alunos questionarem por que esses eventos ocorreram em tempos e lugares específicos, incluindo o presente. Existe o perigo de assumir uma tendência masculina inata de cometer violência sexual, ao invés de compreender a historicidade

\footnotetext{
${ }^{10}$ Aqui, não pretendemos discutir a obra de Elisabeth Crouzet-Pavan, pois o livro didático nos fornece apenas um pequeno recorte/fragmento que, para isso, necessita ser apreendido no conjunto da obra em que se insere. $O$ que colocamos em questionamento são os usos e apropriação desse mesmo fragmento no livro didático.
} 
desse comportamento, bem como de seus significados e modos de funcionamento na vida social. A naturalização do desejo sexual masculino desenfreado se reflete na indiferença em relação à violência sexual na história. Essa suposição nociva tende a apagar os fatores sociais que tornam esse tipo de violência tão predominante. Ao situar a violência sexual, bem como as masculinidades que a produzem em seu contexto histórico específico, podemos romper com justificativas para esse tipo de violência, baseadas em supostos princípios biológicos.

\section{Estupros em cenários de escravidão e colonialismo}

A coleção História Global menciona que as mulheres negras nas Minas Gerais, em tempos de escravidão, "suportariam uma dupla exploração: sexual e econômica” e que, assim, a "escravidão revelaria uma de suas faces mais severas" (COTRIM, 2016, p. 337). Trata-se de uma imagem que fixa um modo de subjetivação das mulheres negras como corpos capazes de "suportar" o estupro e, concomitantemente, a exploração econômica. Assim, o livro didático parece informado pelos mesmos estereótipos racistas ${ }^{11}$ e sexistas que circulam intensamente no cinema, na televisão, na música e em outros artefatos culturais, perpetuando a imagem dessas mulheres como seres fortes e capazes de suportar e sobreviver à dor, à exploração e à violência extrema.

Como bem disse Bell Hooks (2014, p. 60):

A imagem estereotipada das mulheres negras como fortes e poderosas dominou tanto a consciência da maior parte dos americanos que até a mulher negra é claramente conformada com as noções sexistas de feminilidade e passividade que ela pode caraterizar como resistente, dominadora e forte. Muito do que foi percebido pelos brancos como um traço amazónico nas mulheres negras foi meramente aceitação estoica de situações que não tivemos poder para mudar.

A imagem de mulheres negras que suportavam a adversidade que nenhuma mulher branca supostamente seria capaz de suportar constitui um sinal de "força

\footnotetext{
${ }^{11}$ Cabe ressaltar que o Guia Digital do PNLD diz que essa "obra cumpre com a proposta de ser um veículo de conhecimento que objetiva combater o racismo e a discriminação, em busca de uma sociedade mais igualitária e justa do ponto de vista das relações étnico-raciais, embora esta temática não seja frequentemente abordada nas atividades pedagógicas (BRASIL, 2017b, p. 37).
} 
animalesca sub-humana" (HOOKS, 2014, p. 59). Trata-se de uma concepção racista/sexista, informada por ideias acerca da natureza feminina negra que emergiram durante o século XIX (HOOKS, 2014). Desse modo, o livro didático perpetua uma imagem colonial que tende a normalizar/naturalizar a violência sexual sofrida cotidianamente por essas mulheres em nossa sociedade, desumanizando-as e excluindo-as como sujeitos de direito humanos. Essa dimensão simbólica e estruturante do estupro, produzida na intersecção entre escravidão e patriarcado, ainda tem efeitos imediatos, pois as mulheres negras são as maiores vítimas de estupro no Brasil ${ }^{12}$.

Sobre colonialismo e estupro de mulheres negras na África, a coleção Cenas da História, ao tratar do tema "Partilha da África", menciona o "extremo da violência" no Congo, cometida pelos colonizadores belgas no fim do século XIX, ao permitir "o saque das vilas, o assassinato dos homens e o estupro das mulheres", estimando que "essas ações chegaram a vitimizar entre 8 a 10 milhões de indivíduos" (GRANGEIRO, 2016, p. 75). Nesse enunciado, observa-se que o destino dos homens é a morte, enquanto o das mulheres é o estupro. Essa forma de tratamento do corpo das mulheres, até o último limite no que eles podem oferecer, denota uma violência e exploração ainda mais cruel e sem precedentes sobre o corpo de mulheres-colonizadas. Visto como alvo de ocupação e anexação, o estupro de seus corpos expressa uma subjetivação marcada simultaneamente pela diferença de gênero e de raça. Esse ato de estupro expressa, ainda, a subjetivação dos sujeitos brancos-masculinos no poder e no controle do corpo das mulheres-colonizadas, constituindo uma ferramenta do colonialismo patriarcal e racista que ainda persiste no tempo presente.

Em tais memórias de estupros de mulheres negras em cenários de dominação colonial e escravista, observa-se o caráter eurocêntrico da epistemologia ainda dominante na escrita da história escolar e que incide nas formas de inclusão dos povos afrodescendentes como sujeitos subalternizados e vitimizados. Apesar dos avanços no combate à presença de imagens preconceituosas e estereotipadas nos livros didáticos, colocados pelos critérios de avaliação do PNLD e pelas Leis ns. 10.639 (BRASIL, 2003) e

\footnotetext{
${ }^{12}$ Segundo o $13^{\circ}$ Anuário Brasileiro de Segurança Pública (FBSP, 2019), 50,9\% dos casos de estupro registrados em 2018 vitimaram mulheres negras.
} 
11.645 (BRASIL, 2008), ainda se observa um silenciamento da História da África e dos afrodescendentes nos currículos e materiais didáticos escolares. Como bem observou o historiador Anderson Oliva (2017, p. 46-47), ainda predomina nos livros didáticos de História, aprovados no PNLD de 2018, uma perspectiva histórica que concentra "maior atenção nas experiências e perspectivas da História europeia" e que concede "um olhar hegemônico ao 'protagonismo' europeu no devir da humanidade”. Assim, os conteúdos relacionados à história dos afrodescentes, bem como à imagem das mulheres negras, apesar de constituírem critérios eliminatórios das obras no edital do PNLD, não aparecem como alvo de reflexões ou críticas mais contundentes nos pareceres de avaliação de tais coleções (OLIVA, 2017).

\section{Estupros e prostituição forçada de meninas na Guerra de Canudos}

Sobre a História do Brasil, uma narrativa sobre a Guerra de Canudos (1896-97), exposta na coleção Oficina de História, faz menção ao estupro dentre as "cenas de extremo horror" retratadas pelos jornalistas que acompanharam a última expedição militar a Canudos em 1897. Segundo os autores, muitos foram assassinados e tiveram seus corpos queimados, mas "como de horror foi o destino das meninas da comunidade, vítimas de estupro e muitas delas obrigadas pelos soldados a se prostituir" (CAMPOS; PINTO; CLARO, 2016, p. 254). A expressão "como de horror" destaca a continuidade e normalidade dessa prática na história. Assim, os estupros e a prostituição forçada expõem uma situação precária de inferiorização, violência, assujeitamento e exploração sexual imposta pelos soldados às mulheres de Canudos. Trata-se de uma representação do estupro coletivo como sanção social, que evidencia não só o poder, a supremacia e as formas de governabilidade patriarcal do Estado brasileiro, mas também as chaves de construção/reprodução de masculinidades viris nas guerras. Sobre isso, os estudos feministas chamam atenção para o modo como tais narrativas, igualmente difusas no cinema e em outras mídias, tendem a influenciar especialmente os homens,

[...] já que a sociedade não só valoriza como positivo o uso da força na resolução de conflitos, mas também os homens que utilizam a violência, produzindo um efeito de sanção social positiva, já que a "masculinidade" 
tem sido uma representação em si mesma da legitimidade da violência e da imposição dos fortes sobre os fracos (BERNÁRDEZ; GARCíA; GONZÁLEZ, 2008, p. 42, tradução nossa).

Embora os avaliadores do PNLD destaquem que a coleção Oficina de História “incentiva o combate à violência de gênero e ao racismo" (BRASIL, 2017a, p. 80), nota-se que o enunciado sobre a Guerra de Canudos tem sérias implicações na educação para a superação da violência sexista e racista contra as mulheres. Em determinados conflitos armados, os estupros coletivos fizeram parte de campanhas sistemáticas e massivas de terror, por isso, causam enorme espanto. No entanto, os modos de rememorização desses estupros abrem uma enorme ferida nos livros didáticos, ao fixar imagens de mulheres pobres e afrodescendentes, como a maioria das mulheres de Canudos, em situação de horror, violência, aprissionamento, sofrimento e morte.

Como bem assinala Verena Alberti (2014, p. 3):

Não que o horror não precise ser estudado e conhecido, mas é preciso saber trabalhá-lo. Não cabe ao professor dar-se por satisfeito depois de chocar os alunos com algumas imagens e cenas; deixá-los com a sensação de bolo no estômago depois de assistirem a um filme, e passar para o tópico seguinte, dando aquele por encerrado. [...] o ensino de questões sensíveis e controversas não tem como objetivo chocar ou apenas dar a conhecer eventos chocantes do passado. O objetivo é suscitar a reflexão dos alunos. É preciso saber passar de fase, nesse jogo: da sensibilização para a reflexão.

Enquanto professores, podemos assumir a tarefa de problematizar o enunciado no livro didático, desvelando também a historicidade de suas memórias e representações.

É nesse sentido que podemos lançar, em sala de aula, alguns questionamentos:

- Como as mulheres de Canudos são retratadas na narrativa e imagem do livro didático?

- Quais são as implicações dessa imagem para as mulheres e os homens?

- Que ponto de vista predomina nessas imagens?

- Que outras versões dessa história poderiam ser apresentadas?

- Quais são os significados e as implicações do estupro e da prostituição forçada de meninas naquele contexto? 
- Quem eram aquelas mulheres?

- Os estupros coletivos são fenômenos restritos às guerras?

- Afinal, por que os estupros coletivos se repetem em quase todas as guerras mencionadas nos livros didáticos?

- Quais são as consequências dessa violência para as mulheres?

Como bem afirma Janie Leatherman (2013, p. 22), os estupros coletivos nas guerras "implicam em múltiplos perpetradores que agridem sexualmente a uma vítima em particular e que resultam em consequências físicas e psicológicas devastadoras".

\section{Estupros nas guerras contemporâneas}

A coleção História cita, ainda, os estupros de mulheres chinesas cometidos pelos soldados japoneses em 1937, durante a Segundo Guerra Mundial, na conquista dos territórios de Nanquim (SANTOS et al., 2016, p. 97). Trata-se de memórias traumáticas e bastante controversas no tempo presente, pois tais atos de violência ainda são interpretados como necessários para "manter a disciplina" das tropas e proporcionar descanso e lazer aos soldados ${ }^{13}$. Os corpos dessas mulheres aparecem como alvo de anexação, como um território a ser ocupado e conquistado, cuja posse sexual devia ser distribuída entre os homens-soldados, como corpo escravo, servil, concubino e de exploração sexual no contexto de guerra. Assim, o ato de estupro pode apresentar-se como forma de construção e reconstrução da masculinidade dos soldados, como forma de tributo pago pelas mulheres à virilidade dos homens na guerra. Esse episódio também demanda historicização em sala de aula, para que possamos romper com os discursos históricos que tendem a naturalizar os estupros nas guerras como resultado de uma necessidade sexual dos soldados.

Segundo Joanna Bourke (2009, p. 14, tradução nossa), o trabalho de historicização do estupro deve situar-se "em oposição a explicações essencialistas como as da

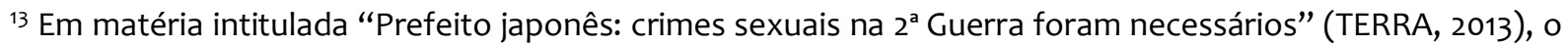
Prefeito de Osaka, no Japão, afirmou que a prostituição forçada pelo Exército de milhares de pessoas na Ásia antes e durante a $2^{a}$ Guerra Mundial foi necessária para "manter a disciplina" nas tropas e proporcionar descanso aos soldados que arriscavam suas vidas no campo de batalha, de acordo com informações da agência Associated Press.
} 
psicologia evolutiva, que defende a existência de uma continuidade da conduta sexualmente violenta, cujas origens remontam a nossos antepassados mais longínquos, que inclusive podem localizar-se nos genes (masculinos)". Portanto, os estupros demandam abordagens que exponham seu caráter histórico-cultural, tendo em vista o desvelamento de seus mecanismos de reprodução e funcionamento em diferentes contextos. Assim, rejeitando as concepções do estupro como um fenômeno a-histórico, expressas na afirmação de que, por natureza, todos os homens são estupradores em potencial, o ensino de História pode nos mostrar que essa violência tem raízes profundas em questões políticas, econômicas e culturais concretas (BOURKE, 2009).

Já a coleção História Global traz um exercício baseado na leitura de um pequeno relato das "monstruosidades" contra as crianças e mulheres judias nos campos de concentração nazistas. Uma parte desse relato diz que

[...] os sobreviventes se recordam primeiro das crianças. Falam dos bebês arremessados vivos nos crematórios, dos moribundos corroídos pelas doenças injetadas pelo médico de Auschwitz, doutor Josef Mengele; dos concursos de arremessos de crianças judias entre os guardas da SS. Também falam das mulheres; as mais jovens estupradas repetidamente antes de mortas, seus corpos usados como tochas humanas em fogueiras de mortos - a carne delas, constataram os guardas, queima mais rápido. Quando pergunta-se sobre as pilhas de corpos, as testemunhas lembram de ratazanas mordiscando os cadáveres; de prisioneiros ainda vivos lutando para se expelir de uma montanha de mortos; de mulheres grávidas abortando fetos. E do cheiro, dizem todos.

II Guerra Mundial. Fábrica da Morte [Revista Veja Online, 2016] (COTRIM, 2016, p. 333, grifo nosso).

Novamente, o horror vem à tona, mas com o objetivo de ressignificar tais atos de estupro como "monstruosidades". Trata-se de uma representação que retira o caráter humano e histórico da violência sexual desencadeada naquele contexto. Atribuir sentidos a essa experiência dos estupradores não é uma tarefa nada fácil. Desse modo, centrar a atenção nos sujeitos perpetradores dos estupros impõe ainda mais dificuldades (BOURKE, 2009). A desumanização selvagem dos estupradores estabelece uma distinção e barreira fundamental entre "eles" e "nós". No entanto, como bem explica Bourke (2009, p. 14, tradução nossa), a humanização dos estupradores é, ao mesmo tempo, algo positivo e perturbador: 
Positivo porque os retira da categoria de monstros inumanos e, por conseguinte, faz com que suas ações sejam suscetíveis de mudança; pertubador porque nos arriscamos a familiarizar e acostumar em excesso com o terrível dano que provocam (BOURKE, 2009, p. 14, tradução nossa).

Atentando para esse problema semântico, é importante que os livros didáticos tenham cuidado na forma de nomear ou adjetivar os estupradores, pois as maneiras estereotipadas de vê-los e tratá-los (como monstros, irracionais ou loucos) não possibilita um enfrentamento mais amplo dessa violência na vida social, já que tende a encerrar esse problema no indivíduo, tratando-o (ou punindo-o) de modo isolado ou individual, desconsiderando a persistência desse problema como um fato social, realimentado cotidianamente por meio de imagens, memórias e práticas que subjetivam masculinidades dominantes na posse de e na violência contra corpos femininos.

A partir do depoimento exposto acima, o livro pede aos estudantes que debatam com os colegas a seguinte questão: “quais seriam as origens da violência e da maldade?" (COTRIM, 2016, p. 333). O Manual do Professor chama nossa atenção pela resposta que confere a essa indagação, ao classificá-la como pessoal e explicar que se trata de um tema “complexo e de amplitude filosófica", propondo que "os/as estudantes devem conversar com os/as professores/as de Filosofia e Sociologia e, tanto quanto possível, ler autores que tratam do tema (Konrad Lorenz, Hannah Arendt, Sigmund Fred etc.)" (COTRIM, 2016, p. 333). Não por acaso, retira-se da história a responsabilidade de oferecer qualquer explicação dessa violência qualificada como monstruosa, demonstrando dificuldades no enfrentamento de temas sensíveis evocados por relatos perturbadores de violências e injustiças.

Por outro lado, pode-se perceber como esse mesmo livro didático se situa na confluência de uma rede de discursos que são controversos ou contrários, o que denota suas tensões e ambivalências na abordagem da violência sexual na história. Assim, traz as concepções de Sigmund Freud que reafirmam o caráter instintivo do estupro e da agressividade como parte da natureza do "homem".

Vejamos o enunciado do seguinte exercício: 
2. Leia o texto escrito em 1930 por Sigmundo Freud, médico que desenvolveu a teoria psicanalítica.

Os homens não são criaturas gentis que desejam ser amadas e que, no máximo, podem defender-se quando atacadas; pelo contrário, são criaturas entre cujos dotes instintivos deve-se levar em conta uma poderosa quota de agressividade. Em resultado disso, o seu próximo é, para eles, não apenas um ajudante potencial ou um objeto sexual, mas também alguém que os tenta a satisfazer sobre ele a sua agressividade, a explorar sua capacidade de trabalho sem compensação, utilizá-lo sexualmente sem o seu consentimento, apoderar-se de suas posses, humilhá-lo, causar-lhe sofrimento, torturá-lo e matá-lo. Homo homini lupus (O homem é o lobo do homem). Quem, em face de toda sua experiência da vida e da história, terá coragem de discutir essa asserção? (FREUD, S. O mal-estar na civilização. In: Os Pensadores. São Paulo: Abril, 1978, p. 167).

a) Considerando que o texto foi concebido no período pós-Primeira Guerra Mundial e na época de ascenção dos regimes totalitários, que resposta você daria à afirmativa (assertiva) final de Freud?

b) Converse com os colegas: você concorda com a concepção de ser humano esboçada no texto? Justifique sua resposta (COTRIM, 2016, p. 53).

Embora o exercício coloque em questionamento as afirmações de Freud, sua “asserção" é bastante desafiadora, já que ele pergunta quem terá “coragem” de discutila. Afinal, trata-se de uma teoria psicanalítica que até hoje detém enorme prestígio e autoridade na ciência, medicina e criminologia ocidental. Desse modo, o próprio exercício tende a reafirmar as verdades colocadas por Freud. Ao sugerir que se trata de uma concepção de "ser humano" esboçada por Freud, o exercício pergunta aos estudantes se eles concordam com essa concepção e pede que justifiquem sua resposta. Com isso, criase a possibilidade de uma conversa e debate em sala de aula que inclui o tema violência sexual. No entanto, para isso, os professores de história precisam estar bem preparados para historicizar o tema, bem como os acontecimentos vivenciados e interpretados por Freud; para não correr o risco de reafirmar estereótipos em torno do estupro, junto com a ideia de exploração, humilhação, tortura e assassinatos como parte da satisfação da natureza humana, onde a culpa é posta sempre no "outro", como alguém que tenta o homem a exercer sobre ele sua agressividade.

O texto de Freud que se coloca em discussão no exercício apresenta uma concepção a-histórica em torno das relações humanas, incapaz de abarcar a diversidade e 
a transformação das relações humanas no tempo e espaço. Sua visão limitada do estupro, como resultado de um instinto sexual masculino descontrolado, tem sérias implicações no tratamento dos estupradores em nossa sociedade, pois coloca o foco apenas em rígidos dispositivos jurídicos de criminalização de tais atos, deixando de lado os investimentos na transfomação da cultura e da educação que promove representações binárias/hierárquicas de sexo-gênero que interpelam os homens, subjetivando-os como sujeitos de poder no domínio sexual das mulheres.

A imagem de vitimização, sofrimento e precariedade das mulheres em contextos de guerra também aparece associada aos estupros de mulheres armênias nas narrativas didáticas sobre o genocídio desencadeado em 1915 pelo governo turco contra a população armênia que vivia nos territórios controlados pelo Império Otomano. Sobre esse conflito, a coleção Cenas da História diz que milhares de armênios foram obrigados a abandonar seus locais de moradia e que:

\begin{abstract}
A maior parte dessas pessoas eram mulheres, crianças e idosos. Ao longo do percurso, muitos deles foram executados ou perderam a vida devido a fome ou doenças. Diversas mulheres foram violentadas e tiveram seus filhos raptados. Os homens armênios, por sua vez, eram obrigados a ir para os campos de batalha, onde eram colocados para cavar trincheiras e, depois, mortos a tiros pelos soldados turcos (GRANGEIRO, 2016, p. 145, grifo nosso).
\end{abstract}

O termo "violentadas" aparece como sinônimo de "estupradas", assinalando o caráter de violência dos estupros, associados ao genocídio do povo armênio. Nesse contexto, o estupro também denota o tratamento diferenciado de gênero na guerra, embora nada seja dito sobre isso, enquanto a Figura 1 fixa os resultados dessa guerra para as mulheres armênias, revelando-as em situação precária e de sofrimento, onde sua força de trabalho passa a ser explorada. Para os homens, a guerra aparece como palco de exercício de masculinidades dominantes, mas também de morte das masculinidades perdedoras. Assim, as narrativas didáticas fixam a política de gênero das guerras contemporâneas, construindo masculinidades-dominantes e feminilidades-dominadas, tendendo a naturalizar a relação da masculinidade com a guerra, bem como o estupro enquanto forma de dominação e resolução de conflitos. 
Figura 1. Mulheres armênias tecem colchas em Alexandroupoli (Grécia, 1915-1922).

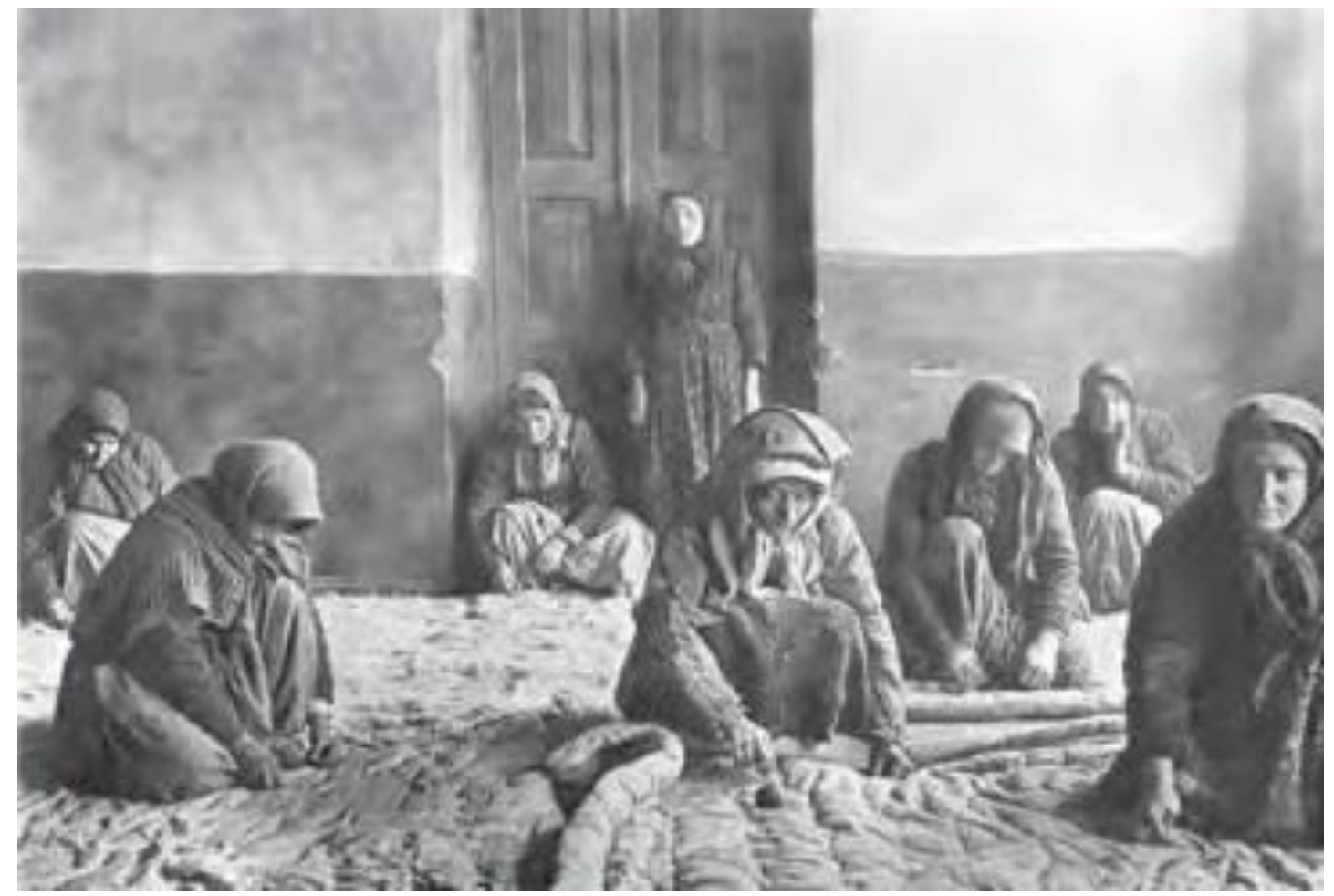

Fonte: Grangeiro (2016, p. 145).

As imagens de guerra associadas à violência sexual tendem a fixar nos livros didáticos um modelo binário de sexo-gênero que constrói o masculino e o feminino como duas entidades que se confrontam e se contra-opõe, mas que dão sentido uma a outra. A violência de gênero como simbolismo das injustiças e crueldades ocorridas em uma guerra tende a reduzir o protagonismo das mulheres na história, pois segue representando-as de modo negativo e estereotipado, perpetuando a desigualdade e violência de tipo simbólico que ainda predomina em nossa sociedade. É isso que também se observa na Figura 2, de uma mulher nua e dominada nos braços de um homem, junto a uma narrativa do volume 2 da coleção História sobre as guerras pela unificação da Itália no século XIX. A legenda diz: "nesta imagem, a mulher representa Roma; o homem que a segura, Vítor Emanuel II; e o clérigo, ao chão, o papa Pio IX. 
Figura 2. Desenho do século XIX (autor desconhecido).

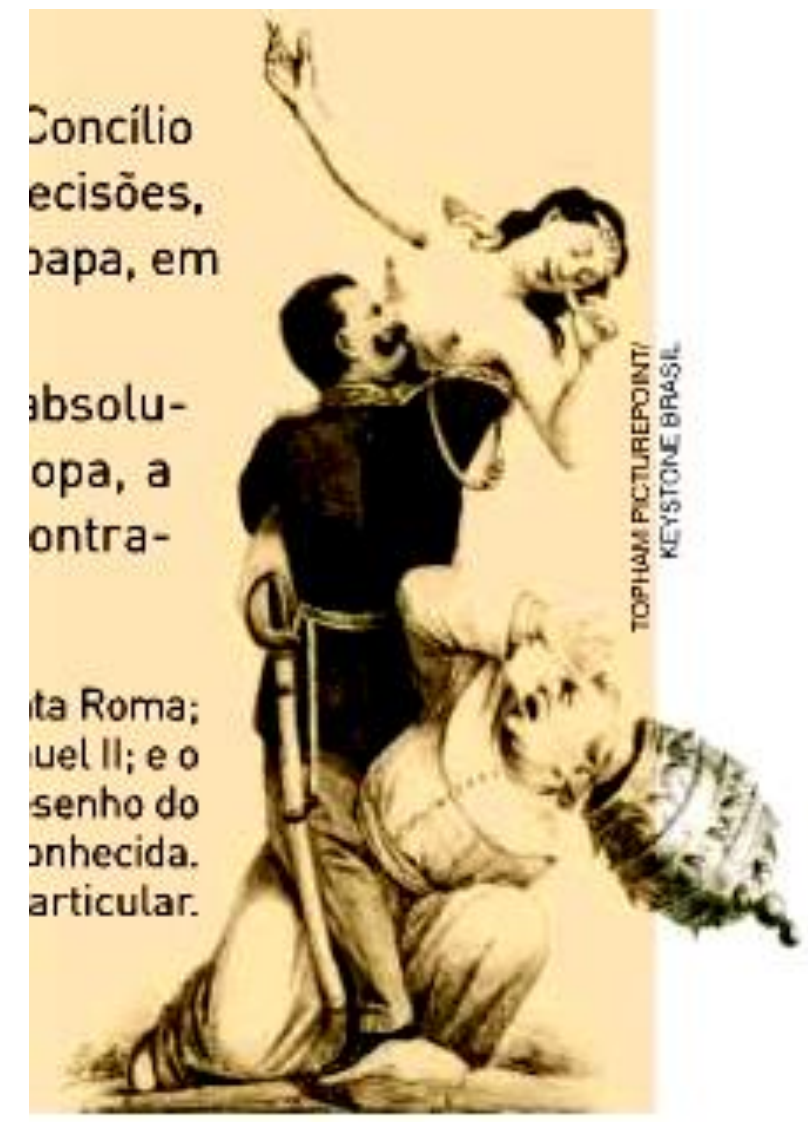

Fonte: Santos et al. (2016, p. 142).

Esse tipo de imagem, assim como a das mulheres armênias na Grécia, expressa apenas o poder, a vitória, a força e a superioridade dos homens na história. A violência sexual contra as mulheres revela, assim, sua dimensão expressiva.

Como bem assinala Rita Segato (2016, p. 79, tradução nossa), o estupro em cenários de guerra

[...] não é uma anomalia de um sujeito solitário, é uma mensagem de poder e apropriação pronunciada na sociedade. O propósito dessa crueldade não é instrumental. Esses corpos vulneráveis no novo cenário de guerra não estão sendo forçados a prestar um serviço, mas há uma estratégia voltada a algo muito mais central, uma pedagogia da crueldade em torno da qual todo o edifício do poder gravita.

Os modos de rememorização dos estupros nas narrativas didáticas e de outros artefatos culturais da contemporaneidade fazem com que nos acostumemos a esse tipo de violência, colaborando na banalização de uma prática de terror às mulheres. Ao 
orientar o nosso olhar e sentimentos à normalidade, indiferença e tolerância em relação a tais atrocidades nas guerras e mesmo em nosso cotidiano, tais narrativas ensinam a não ter empatia com as vítimas, o que funciona como uma pedagogia da crueldade contra as mulheres (SEGATO, 2016). Desse modo, algumas narrativas de livros didáticos podem acabar colaborando na revitimização das mulheres que sofreram tais agressões ao promover a banalidade, a espetacularização e a naturalização de tais práticas no social.

\section{Ensino de História no combate à violência sexual}

Após a Segunda Guerra Mundial, os livros didáticos, especialmente dos países envolvidos nesse conflito, tornaram-se alvo de vigilância, preocupação e controle por parte de instituições internacionais, como a Organização das Nações Unidas para a Educação, a Ciência e a Cultura (UNESCO), pelo receio de que visões estereotipadas de grupos e populações pudessem instigar novamente uma guerra entre nações (BITTENCOURT, 2011). Hoje, as memórias de estupros de guerra também devem suscitar preocupações e avaliações. Trata-se de memórias domesticadas por histórias capazes de despertar sentimentos misóginos e desejos de dominação sexual das mulheres como forma de guerra, governo, resolução de conflitos, demonstração de poder e masculinidade viril, constituindo potentes referenciais políticos onde o principal inimigo e oponente passa a ser o corpo das mulheres e, especialmente, de mulheres racializadas.

Apesar das vitórias no campo jurídico, como a implementação de leis e políticas públicas de proteção às mulheres ${ }^{14}$, a violência contra corpos femininos e feminizados tem aumentado, especialmente no contexto das novas guerras (SEGATO, 2014). Mesmo com o surgimento de acordos e tratados internacionais sobre crimes de guerra e violação

\footnotetext{
${ }^{14}$ A Convenção Interamericana para Prevenir, Punir e Erradicar a Violência contra a Mulher (Convenção de Belém do Pará), adotada em 09/06/1994 e promulgada pelo Decreto n. 1.973 (BRASIL, 1996), afirma que "a violência contra a mulher constitui violação dos direitos humanos e liberdades fundamentais e limita todas ou parcialmente a observância, gozo e exercício de tais direitos e liberdades". Segundo os artigos 1 e 2, do Capitulo I dessa Convenção, entende-se que a violência contra a mulher abrange a violência física, sexual e psicológica: “a) ocorrida no âmbito da família ou unidade doméstica ou em qualquer relação interpessoal, quer o agressor compartilhe, tenha compartilhado ou não a sua residência, incluindo-se, entre outras turmas, o estupro, maus-tratos e abuso sexual; b) ocorrida na comunidade e comedida por qualquer pessoa, incluindo, entre outras formas, o estupro, abuso sexual, tortura, tráfico de mulheres, prostituição forçada, seqüestro e assédio sexual no local de trabalho, bem como em instituições educacionais, serviços de saúde ou qualquer outro local; e c) perpetrada ou tolerada pelo Estado ou seus agentes, onde quer que ocorra" (BRASIL, 1996).
} 
de direitos humanos, com cláusulas para a proteção das mulheres nas guerras, os conflitos armados, desde o século XX, têm piorado a situação para os civis e, em especial, para as mulheres, com o aumento dos estupros e abusos sexuais (SEGATO, 2014) ${ }^{15}$. Ainda de acordo com Segato $(2014,2016)$, esse aumento ascendente da violência feminicida é resultado dos avanços do capitalismo patriarcal, racista e colonial na promoção de uma guerra contra as mulheres. As novas formas de guerra na contemporaneidade colaboram na introdução do patriarcado e sua política de gênero na vida das populações em conflito $^{16}$.

Não por acaso, o $13^{\circ}$ Anuário Brasileiro de Segurança Pública (FBSP, 2019), divulgado recentemente, aponta o aumento da violência sexual e do feminicídio, ao informar que foram 66.041 vítimas de estupro no Brasil em 2018 - o maior índice já registrado. O FBSP (2019) informa, ainda, que $81,8 \%$ das vítimas eram do sexo feminino, 53,8\% tinham até 13 anos, 50,9\% eram negras e 48,5\% eram brancas. Foram registrados 180 estupros por dia um aumento de 4,1\%. Por isso, o próprio FBSP (2019) destaca a importância das escolas educarem sobre igualdade de gênero e violência sexual. Nesse sentido, as memórias de violência sexual exigem um tratamento especial nos livros didáticos e no ensino de História.

É necessário que os livros didáticos não deixem de mencionar as resoluções internacionais para os crimes de guerra ${ }^{17}$, onde o estupro passa a ser caracterizado como

\footnotetext{
${ }^{15}$ Episódios recentes de ataques sexuais em cenários de guerra no Iraque, na Síria, na Nigéria, no Congo e no Sudão têm revelado o impacto das novas guerras nos corpos das mulheres. "grupos extremistas como o Estado Islâmico e o Boko Haram estão recorrendo cada vez mais ao estupro e à violência sexual como tática de guerra. No Iraque, a tomada de Mossul pelo Estado Islâmico promoveu a escravidão sexual de mulheres jovens, sobretudo da minoria cristã yazidi, vendidas como escravas em feiras ou dadas como presente a combatentes, segundo o relatório da ONU [Organização das Nações Unidas]. Em relatório publicado pela ONU em 2016, o Boko Haram da África Ocidental aparecia entre os 13 grupos ou facções que recorriam à violência sexual como forma de atrair maior atenção internacional para seus conflitos. [...] Além desses exemplos, observamos o drama recente de mulheres norte-americanas que foram para a guerra do Iraque, como soldadas, e foram estupradas e assediadas sexualmente pelos próprios colegas e superiores nas Forças Armadas" (S. R. OLIVEIRA, 2017, p. 159-160).

16 Concordamos com Rita Segato (2016, p. 161-162) que os estupros de guerra não resultam de uma continuidade das relações patriarcais em âmbito doméstico. Nos últimos tempos, é a guerra que realimenta o patriarcado, pois a produção da violência bélica e cruel sobre os corpos das mulheres tende a retornar ao campo doméstico, subjugando as mulheres e afetando a confiança comunitária.

${ }^{17}$ Com a Convenção de Genebra de 1949, o estupro passou a figurar na lista de crimes contra a humanidade, como parte da tortura, dos crimes de guerra e de genocídio. Essa convenção não apresenta uma dimensão de gênero, pois estabelece a proteção às mulheres em virtude de suas diferenças biológicas, especialmente, pela função social reprodutiva de seus corpos como gestantes e mães, a partir de uma
} 
forma de tortura e genocídio. Além disso, a educação para a superação da violência sexual demanda a elaboração de narrativas didáticas que desnaturalizem as razões, os significados e as implicações dessa violência, desvelando, também, as conexões dessa violência com variados eixos de dominação (de gênero, raça, classe, etnia etc.). A enfase na violência sem a devida visibilidade do protagonismo, da resistência, da organização e da identidade das mulheres que sofrem essa violência na história tende a cristalizar imagens e memórias de vítimas-femininas e agressores-masculinos. Nesse sentido, mostra-se necessário trazer memórias de atuação das mulheres nos mesmos cenários onde a violência sexual ocorreu, para também lhes conferir o status de sujeito histórico nos enredos narrativos. Como exemplo, podemos mostrá-las como combatentes ou ativistas em organizações ${ }^{18}$ que tentam intervir em processos de paz, a favor do desarmamento e da prevenção das guerras (SÁNCHEZ, 2016). Embora alguns livros didáticos tragam outras formas de representação das mulheres nas guerras, ainda que de modo controverso, destacando seu protagonismo nas batalhas como combatentes, vivandeiras (SANTOS et al., 2016) ou enfermeiras (GRANGEIRO, 2016), observa-se que os modos de rememorização dos estupros de guerra integram narrativas que tendem a fixar a violência que vitimiza e inferioriza, especialmente, as mulheres. Mais um motivo, portanto, para que o ensino de História assuma o compromisso de ser uma instância de valorização de subjetividades positivas e plurais, assentada no reconhecimento da memória como princípio fundador da construção da igualdade de gênero.

ótica paternalista que vincula a imagem das mulheres à de vítimas vulneráveis, de menores de idade ou de instrumentos reprodutivos (SÁNCHEZ, 2016). O Conselho de Direitos Humanos da ONU só reconheceu em 1993 a prática de estupro como crime de guerra. Os motivos para essa demora na inclusão da temática do estupro em contextos de guerra no direito internacional se deve à persistência de valores patriarcais no campo jurídico, onde questões ligadas aos direitos, interesses e bem-estar das mulheres ganharam pouca ou nenhuma importância. Em 2000, o Conselho de Segurança da ONU aprovou a Resolução n. 1.325 sobre mulheres, paz e segurança, introduzindo finalmente o conceito de "violência por motivos de gênero" no contexto dos conflitos armados. Com isso, a consideração da violência baseada no gênero no Direito Internacional Humanitário deixa de ser uma questão marginal e passa a ser uma questão central de atenção (BRASIL, 2017c, p. 45). O Brasil adotou esses principios, em 2017, no Plano Nacional de Ação sobre Mulheres, Paz e Segurança (BRASIL, 2017C), vigente por um período de 2 anos (2017-2019).

18 Ver, por exemplo, a atuação da Liga Internacional de Mulheres pela Paz e Liberdade (Women's International League for Peace and Freedom - WILPF), que desde sua fundação, em 1915, reúne mulheres de todo o mundo com o objetivo de trabalhar pela paz por meios não violentos e promover justiça política, econômica e social para todos. A abordagem dessa organização não governamental (ONG) internacional é a não violência, para tanto, usa estruturas legais e políticas internacionais existentes para alcançar uma mudança fundamental na forma como os Estados conceitualizam e abordam questões de gênero, militarismo, paz e segurança (cf. WILPF, 2018). 
A falta de problematização do tema violência sexual nos livros didáticos, aponta a permanência de uma tradição escolar que olha o passado como algo distante no tempo, sem qualquer conexão com o presente, o que permite a desumanização dos sujeitos históricos que sofreram tal violência. Esse tipo de abordagem cumpre apenas a função de enfatizar a precariedade da vida desses sujeitos na história, sem que isso signifique uma vontade de protegê-los ou garantir as condições de sua sobrevivência e prosperidade no tempo presente.

Como bem assinala Judith Butler (2015, p. 15), se queremos ampliar as

[...] reivindicações sociais e políticas sobre os direitos à proteção e o exercício do direito à sobrevivência e à prosperidade, temos antes que nos apoiar em uma nova ontologia corporal que implique repensar a precariedade, a vulnerabilidade, a dor, a interdependência, a exposição, a subsistência corporal, o desejo, o trabalho e as reivindicações sobre a linguagem e o pertencimento social.

A apreensão da precariedade conduz "a uma potencialização da violência, a uma percepção da vulnerabilidade física de certo grupo de pessoas que incita o desejo de destruí-las" (BUTLER, 2015, p. 150).

Como bem apontam os feminismos decoloniais,

[...] é violência a maneira como os corpos outros são olhados, construídos, tratados, valorizados e atendidos. É violência a não escuta, o não reconhecimento de saberes, de subjetividades. É violência negar as vivências, negar outras epistemologias e narrativas que questionam a história oficial (CRUZ, 2017, p. 35, tradução nossa).

O predomínio de representações que revitimizam mulheres racializadas em cenários de conflitos sociais, retratando-as como submersas na dor, infelicidade, precariedade, pobreza, fome, dominação e em situações de morte, traz enormes prejuízos ao ensino de História na educação para os direitos humanos das mulheres. Ao ocultar a dignidade e direito dessas mulheres, nega-Ihes a expressão como ser político, de identidade cultural, de humanidade e de luta na superação e libertação de situações de violência, opressão e discriminação social.

Devemos ressaltar que o PNLD 2018 representa conquistas importantes e positivas na promoção da educação para o combate à violência contra as mulheres no Brasil. 
Porém, as dificuldades no atendimento pleno a essas prescrições se encontram, ainda, na própria epistemologia sexista/racista que tradicionalmente orienta a escrita da história escolar, impedindo que as concepções binárias e hierárquicas de sexo-gênero sejam desafiadas pelas narrativas didáticas. Assim, queimar, ignorar ou excluir os livros didáticos que trazem representações de violência sexual não vai resolver os problemas enraizados em nossa cultura. Independentemente da qualidade do livro, ele necessita ser problematizado em sala de aula, para que os estudantes aprendam a questionar, interpretar e refletir sobre memórais e histórias de violência sexual que circulam na escola e em outros artefatos culturais da contemporaneidade.

Não por acaso, os livros didáticos analisados evitam historicizar o sexo-gênero, revelando os limites de suas abordagens no sentido da promoção de uma educação para o combate à violência contra mulheres. Essa historicização poderia colocar em xeque os valores, as crenças e as verdades que alicerçam as desigualdades estruturais de nossa sociedade, também abrindo condições discursivas para a emergênia de outros modos possíveis de subjetivação do sexo-gênero. Cabe ressaltar, ainda, que, desde 2014, as escolas brasileiras vêm tornando-se alvo das ações do movimento Escola Sem Partido, que, na luta contra a chamada "ideologia de gênero", busca promover a censura aos termos "gênero" e "sexualidade nos planos educacionais, alegando que qualquer questionamento em torno desses termos constitui um crime contra a família. Como explica Miskolci (2018, p. 8), essa censura impede “o aprendizado de meios para a demanda de igualdade e autonomia por parte de mulheres, assim como o de direitos fundamentais como segurança e respeito à própria vida no caso de homossexuais, pessoas trans, entre outras". Nesse cenário político, vemos nosso direito de liberdade de expressão ameaçado por projetos de lei que proíbem os professores de usar os termos "gênero" ou "orientação sexual" em sala de aula, como bem noticiou o relatório da Human Rights Watch (2018) sobre a violação de direito humanos no Brasil. Enfim, como bem disse Verena Alberti (2014, p. 2), para abordar temas sensíveis na escola é necessário, antes de tudo, um ambiente seguro, "onde alunos e professores se sintam confortáveis para discutir o assunto". Em tempos difícieis como esse é importante que os professores e a escola estejam, portanto, dispostos a correr riscos e lutar pela educação democrática no Brasil. 


\section{Referências}

ALBERTI, Verena. O professor de história e o ensino de questões sensíveis e controversas. In: COLÓQUIO NACIONAL HISTÓRIA CULTURAL E SENSIBILIDADES, 4., 2014, Caicó. Anais... Caicó, RN: Universidade Federal do Rio Grande do Norte, 2014.

BECHLER, Rosiane Ribeiro; SILVA, Cristiani Bereta da. Livros didáticos como textos de memória: notas sobre narrativas da imigração alemã em livros didáticos de história regionais. Revista História da Educação, Porto Alegre, v. 23, p. 1-32, 2019.

BERNÁRDEZ, Asunción; GARCÍA, Irene; GONZÁLEZ, Soraya. Violencia de género en el cine español: análisis de los años 1998 a 2002 y guía didáctica. Madrid: Ed. Complutense, 2008.

BERTRAM, Corrine C.; CROWLEY, M. Sue. Teaching about sexual violence in higher education: moving from concern to conscious resistance. Frontiers: A Journal of Women Studies, Lincoln, v. 33, n. 1, p. 63-82, 2012.

BITTENCOURT, Circe Maria Fernandes. Produção didática de História: trajetórias de pesquisas. Revista de História, São Paulo, n. 164, p. 487-516, 2011.

BOURKE, Joanna. Los violadores: historia del estupro de 1860 a nuestros días. Barcelona: Crítica, 2009.

BRASIL. Decreto n. 1.973, de $1^{\circ}$ de agosto de 1996. Promulga a Convenção Interamericana para Prevenir, Punir e Erradicar a Violência contra a Mulher, concluída em Belém do Pará, em 9 de junho de 1994. Diário Oficial da União, Brasília, 2 ago. 1996.

BRASIL. Lei n. 10.639, de 9 de janeiro de 2003. Altera a Lei n. 9.394, de 20 de dezembro de 1996, que estabelece as diretrizes e bases da educação nacional, para incluir no currículo oficial da Rede de Ensino a obrigatoriedade da temática "História e Cultura AfroBrasileira", e dá outras providências. Diário Oficial da União, Brasília, 10 jan. 2003.

BRASIL. Lei n. 11.645, de 10 março de 2008. Altera a Lei n. 9.394, de 20 de dezembro de 1996, modificada pela Lei n. 10.639, de 9 de janeiro de 2003, que estabelece as diretrizes e bases da educação nacional, para incluir no currículo oficial da rede de ensino a obrigatoriedade da temática "História e Cultura Afro-Brasileira e Indígena". Diário Oficial da União, Brasília, 11 mar. 2008.

BRASIL. Edital de convocação para o processo de inscrição e avaliação de obras didáticas para o Programa Nacional do Livro Didático. PNLD 2018. Brasília, DF: Ministério da Educação, 2015. 
BRASIL. Base Nacional Comum Curricular. Ensino Médio. Brasília, DF: Ministério da Educação, 2017a.

BRASIL. PNLD 2018: História - guia de livros didáticos, Ensino Médio. Brasília, DF: Ministério da Educação, 2017b.

BRASIL.Plano Nacional de Ação sobre Mulheres, Paz e Segurança. Brasília, DF: Ministério das Relações Exteriores, 2017c.

BUTLER, Judith. Quadros de guerra: quando a vida é passível de luto? Rio de Janeiro: Civilização Brasileira, 2015.

CAMPOS, Flávio de; PINTO, Júlio Pimentel; CLARO, Regina. Oficina de História. 2. ed. São Paulo: Leya, 2016. v. 2.

CERQUEIRA, Célia; PONTES, Maria Aparecida; SANTIAGO, Pedro. Por dentro da história. 4. ed. São Paulo: Escala, 2016.

CHOPPIN, Alain. História dos livros e das edições didáticas: sobre o estado da arte. Educação e Pesquisa, São Paulo, v. 30, p. 549-566, 2004.

COTRIM, Gilberto. História global. 3. ed. São Paulo: Saraiva, 2016. v. 3.

CRUZ, Úrsula Santa. Más allá del género: resistencia ante la amnesia colonial. In: VASALLO, Brigitte et al. Cultura de la violación: apuntes desde los feminismos decoloniales y contragemónicos. Madrid: Antipersona, 2017. p. 25-37.

FÓRUM BRASILEIRO DE SEGURANÇA PÚBLICA - FBSP. $13^{\circ}$ Anuário Brasileiro da Segurança Pública. São Paulo: FBSP, 2019.

FOUCAULT, Michel. O retorno da moral. Barbedette, Gilles e Scala, André. Entrevista de Michel Foucault. Les Nouvelles, em 29/5/1984. In: ESCOBAR, Carlos Henrique (Org.).

Michel Foucault (1926-1984). O Dossier: últimas entrevistas. Rio de Janeiro: Taurus, 1984. p. 128-138.

GNECCO, Cristóbal. Historias hegemónicas, historias disidentes: la domesticación política de la memoria social. In: GNECCO, Cristóbal; ZAMBRANO, Marta (Org.). Memorias hegemónicas, memorias disidentes: el pasado como política de la historia. Bogotá: Ministerio de Cultura/Universidad del Cauca/Instituto Colombiano de Antropología, 2000. p. 171-194.

GRANGEIRO, Cândido. Cenas da História. São Paulo: Palavras Projetos Editoriais, 2016. v. 3. 
HALL, Stuart. Cultura e representação. Rio de Janeiro: PUC-Rio/Apicuri, 2016.

HENNIGEN, Inês; GUARESCHI, Neuza Maria de Fátima. A subjetivação na perspectiva dos estudos culturais e foucaultianos. Psicologia da Educação, São Paulo, n. 23, p. 57-74, 2006.

HOOKS, Bell. Não sou eu uma mulher: mulheres negras e feminismo. Lisboa: [s.n.], 2014.

HUMAN RIGHTS WATCH. Brasil: Eventos de 2018. 2018. Disponível em:

<https://www.hrw.org/pt/world-report/2019/country-chapters/326447\#714bbb>. Acesso em: 29 set. 2019.

JULIA, Dominique. A cultura escolar como objeto histórico. Revista Brasileira de História da Educação, São Paulo, n. 1, p. 9-43, 2001.

KIMMEL, Michael S. A produção simultânea de masculinidades hegemônicas e subalternas. Horizontes Antropológicos, Porto Alegre, v. 4, n. 9, p. 103-117, 1998.

LAURETIS, Teresa de. A tecnologia de gênero. In: HOLLANDA, Heloísa Buarque de (Org.). Tendências e impasses: o feminismo como crítica da cultura. Rio de Janeiro: Rocco, 1994. p. 206-242.

LEATHERMAN, Janie. Violencia sexual y conflictos armados. Barcelona: Institut Català Internacional per la Pau, 2013.

MACHADO, Lia Zanotta. Masculinidade, sexualidade e estupro: as construções da virilidade. Cadernos Pagu, Campinas, n. 11, p. 231-273, 1998.

MISKOLCl, Richard. Exorcizando um fantasma: os interesses por trás do combate à “ideologia de gênero". Cadernos Pagu, Campinas, n. 53, e185302, 2018.

MISTURA, Letícia; CAIMI, Flávia E. O (não) lugar da mulher no livro didático de História: um estudo longitudinal sobre relações de gênero e livros escolares (1910-2010). Aedos, Porto Alegre, v. 7, n. 16, p. 229-246, 2015.

NÚCLEO DE PESQUISA EM GÊNERO, RAÇA E ETNIA - NUPEGRE. A semântica do estupro coletivo nas ciências sociais, no poder legislativo e no discurso do poder judiciário. Rio de Janeiro: Escola de Magistratura do Estado do Rio de Janeiro, 2018.

OLIVA, Anderson Ribeiro. Desafricanizar o Egito, embranquecer Cleópatra: silêncios epistêmicos nas leituras eurocêntricas sobre o Egito em manuais escolares de História no PNLD 2018. Romanitas: Revista de Estudos Grecolatinos, Vitória, v. 10, p. 26-63, 2017. 
OLIVEIRA, Edlene Silva. Internet, estupro, assédio sexual e ativismo na campanha online “primeiroassédio". In: STEVENS, Cristina et al. Relatos, análises e ações no

enfrentamento da violência contra mulheres. Brasília, DF: Technopolitik, 2017. p. 200-233.

OLIVEIRA, Susane Rodrigues de. O dispositivo amoroso e o assujeitamento das mulheres nas histórias que os livros didáticos ensinam. In: STEVENS, Cristina; OLIVEIRA, Susane; ZANELLO, Valeska; SILVA, Edlene; PORTELA, Cristiane (Org.). Mulheres e violências: interseccionalidades. Brasília: Technopolitik, 2017. p. 205-225.

OLIVEIRA, Susane Rodrigues de. Ensino de História das Mulheres: reivindicações, currículos e potencialidades. In: STEVENS, Cristina; OLIVEIRA, Susane Rodrigues de; ZANELLO, Valeska. Estudos feministas e de gênero: articulações e perspectivas. Florianópolis: Mulheres, 2014. p. 276-291.

OLIVEIRA, Susane Rodrigues de. Guerras e violência sexual nos livros didáticos de história brasileiros: análises e orientações pedagógicas feministas. In: STEVENS, Cristina et al. Relatos, análises e ações no enfrentamento da violência contra mulheres. Brasília, DF: Technopolitik, 2017. p. 131-167.

O PORTAL DE NOTÍCIAS DA GLOBO - G1. Mural em repúdio ao estupro de menina no Rio é instalado na Paulista. 2016. Disponível em: <http://g1.globo.com/saopaulo/noticia/2016/05/ato-de-repudio-ao-estupro-de-jovem-no-rio-acontece-na-avpaulista.html>. Acesso em: 22 jan. 2019.

OSSENBACH, Gabriela. Manuales escolares y patrimonio histórico-educativo. Educatio Siglo XXI, Murcia, v. 28, n. 2, p. 115-132, 2010.

PEREIRA, Nilton Mullet; RODRIGUES, Mara Cristina de M. BNCC e o passado prático: temporalidades e produção de identidades no ensino de História. Arquivos Analíticos de Políticas Educativas, Tempe, v. 26, n. 107, p. 1-22, 2018.

POTTS, Malcolm; HAYDEN, Thomas. Sex and war: how biology explains warfare and terrorism and offers a path to a safer world. Dallas, TX: Benbella, 2008.

SÁNCHEZ, Carolina Jiménez. Las mujeres en los conflictos armados: conflicto, proceso de paz y posconflicto. Málaga, España: Universidad de Málaga, 2016.

SANTOS, Georgina dos et al. História. 3. ed. São Paulo: Saraiva, 2016. v. 2.

SEGATO, Rita Laura. Las nuevas formas de la guerra y el cuerpo de las mujeres. Sociedade e Estado, Brasília, v. 29, n. 2, p. 314-371, 2014.

SEGATO, Rita Laura. La guerra contra las mujeres. Madrid: Traficante de Sueños, 2016. 
TERRA. Prefeito japonês: crimes sexuais na $2^{\text {a }}$ Guerra foram necessários. 2013. Disponível em: <https://www.terra.com.br/noticias/mundo/asia/prefeito-japones-crimes-sexuais-na-2guerra-foram-necessarios,86c886bda81ae310VgnVCM3000009acceboaRCRD.html>. Acesso em: 29 set. 2019.

THORNHILL, Randy; PALMER, Craig T. A natural history of rape: biological bases of sexual coercion. Cambridge, MA: The MIT Press, 2000.

VEIGA-NETO, Alfredo. Foucault \& a educação. 2. ed. Belo Horizonte: Autêntica, 2007.

VICENTINO, Bruno; VICENTINO, Cláudio. Olhares da história: Brasil e mundo. São Paulo: Scipione, 2016. v. 1.

VIGARELLO, Georges. História do estupro: violência sexual nos séculos XVI-XX. Rio de Janeiro: Zahar, 1998.

VIZA, Ben-Hur; SARTORI, Myrian Caldeira; ZANELLO, Valeska (Org.). Maria da Penha vai à escola: educar para prevenir e coibir a violência doméstica e familiar contra a mulher. Brasília, DF: TJDFT, 2017.

WOMEN'S INTERNATIONAL LEAGUE FOR PEACE AND FREEDOM - WILPF. 2018. Our Movement. Disponível em: <https://wilpf.org/wilpf/who-we-are/>. Acesso em: 29 set. 2019. 